\title{
A design and experimental investigation of a large-scale solar energy/diesel generator powered hybrid ship
}

\author{
Yupeng Yuan ${ }^{1,2}$, Jixiang Wang ${ }^{1}$, Xinping Yan ${ }^{1}$, Qing Li ${ }^{1,3}$, Teng Long ${ }^{2}$ \\ 1. Reliability Engineering Institute, School of Energy and Power Engineering\& National Engineering Research \\ Center for Water Transport Safety, Wuhan University of Technology, Wuhan Hubei 430063, China; \\ 2. Department of Engineering, University of Cambridge, Cambridge, CB3 OFA, UK; \\ 3. China waterborne transport research institute, Beijing, 100088, China
}

Abstract: Due to the increasing demand for energy conservation and the reduction of emissions, renewable energy applications for ships have attracted a great deal of attention.

In this paper, a 5000-vehicle space pure car and truck carrier (PCTC) is selected as the research object. Then, on the basis of the existing power system, a unified grid-tied/standalone solar system is designed with a built-in battery energy storage system. The system includes a solar energy generation unit, a battery storage system, a diesel generating set, grid-tied/stand-alone controlled inverters, a battery management system (BMS) and an energy management system. According to an analysis of the experimental data, it can be concluded that the use of solar energy hybrid power can reduce fuel consumption by $4.02 \%$ and carbon dioxide $\left(\mathrm{CO}_{2}\right)$ emissions by $8.55 \%$ a year. Thus, the proposed solar-powered hybrid system can reduce both oil consumption and $\mathrm{CO}_{2}$ emissions significantly.

Keywords: Solar Energy; Hybrid Powered Ship; Grid-tied/stand-alone; Energy Conservation and Emission Reduction

\section{Introduction}

Energy shortages, environmental pollution, and global warming are common challenges

Corresponding author. Yupeng Yuan, Department of Engineering, University of Cambridge, Cambridge, CB3 0FA, UK; Tel: +44 7513 
faced by the global energy community today. The fossil fuel energy systems established in

24 the 20th century are unsuitable for the efficiency, economic, and safety demands of today's society. According to a forecast of the International Energy Agency, the annual global

26

27 energy demand will increase from 12 billion tons of oil equivalent in 2009 , to $17-18$ billion tons of oil equivalent in 2035. Moreover, if the current emissions policy is maintained, emissions will increase from 29 billion tons in 2009 to 43 billion tons in 2035; furthermore, even taking into account the new regulations, emissions will rise to 36 billion tons [1].

Whilst it is an important part of intercontinental communication and economic activity, the shipping industry causes a much higher emission of pollutants than the aviation industry. Additionally, the energy consumption of ships is quite significant and problems such as the exhausting of resources and oil leakages are also severely threatening the environment. Accordingly, the emission requirements for coastal ships, or those sailing on inland lakes, are more stringent [2]. The results of the Greenhouse Gas (GHG) study completed by the International Maritime Organization (IMO) in 2009 showed that in 2007, the global shipping industry's $\mathrm{CO}_{2}$ emissions were approximately 1.046 billion tons, accounting for $3.3 \%$ of the total global carbon dioxide emissions. Moreover, if no restrictions were imposed, by 2050, the $\mathrm{CO}_{2}$ emissions from the shipping industry would increase by $150 \%$ to $250 \%$, accounting for between $12 \%$ and $18 \%$ of the global allowable carbon dioxide emissions [3]. The latest report of the International Energy Agency in October 2017 stated that the current total global carbon dioxide emissions are 800 million 
tons and, according to the IMO, this number will double by 2060. In order to deal with the stringent demands of the regulations relating to ships' emissions, all major shipping nations in the world have adopted "green ships", as these are seen as the future of the shipping industry [4].

Against this background, all countries in the world, including China, are faced with the problem of the structural reform of energy. The development and utilization of clean energy, such as solar energy, wind energy, hydropower, hydrogen energy and liquefied natural gas $(\mathrm{LNG})$, is an effective way of conserving energy and reducing the emissions of ships [5-7]. These clean energy sources, which do not pollute the environment, are increasingly becoming more widely appreciated. Inexhaustible solar energy is a good example of a renewable energy source and in the post-fossil fuel era, it will become one of the most important natural energy sources [8]. To date, solar energy has been widely used on land [9-12]; however, research and development regarding its use as a power source for transport, particularly in water transportation, has been slower to progress. If solar power can be used to provide electricity for ships, or as a propulsion system to replace traditional diesel power, it can greatly reduce both a ship's energy consumption and emissions [13].

However, due to the limitations of solar energy conversion efficiency for ships that have relatively large power requirements and a limited installation area for solar panels, solar energy often needs to be combined with a diesel engine or other energy sources to act as a hybrid power system [14-15]. In recent years, researchers around the world have conducted a large number of studies on the design of solar photovoltaic (PV) systems. For 
example, literature [16] proposed a method of using solar energy and ocean thermal energy as a means of propulsion for ships, and provided a detailed design proposal. Moreover, Zhu Y et al. [17] studied the factors affecting the power generation of solar PV systems for newly constructed ships, and concluded that ships using solar energy as an auxiliary power, at a latitude of 31.9 degrees north, can achieve a reduction in fuel consumption and emissions that meets the requirements of the energy efficiency design index (EEDI). Atodiresei D et al. [18] analyzed the economics of using solar PV systems in commercial ships on the northwest route of the Black Sea Basin. Their results show that at different latitudes and climatic conditions, more energy can be generated by adjusting the optimal angle of the solar panel. Liu H [19] proposed a marine hybrid power system consisting of a diesel generator, solar energy, a battery, and a super capacitor, and established a mathematical model of solar power generation under ocean conditions. Accordingly, the fluctuation characteristics of the solar output power and the optimal capacity of the supercapacitor were analyzed. Although the ship used as the research object was large with a displacement of 5878.8t, the capacity for installing a solar energy system was very small, with only a PV panel area of $1.25 \mathrm{~m}^{2}$. Salem A A et al. [20] proposed a scheme for the installation of marine grid-connected solar power systems, and analyzed their economical and emission characteristics. The authors then used a case study, where the object boat was $43.1 \mathrm{~m}$ in length and the power of the solar energy system was 260 watts, to prove that the proposed power system solution could achieve the dual goal of energy conservation and the reduction of emissions. Atkinson G M [21] used a high-speed 
passenger ship with a deadweight of $2775 \mathrm{t}$ as the research object and designed a solar energy PV system with a peak power of $2.32 \mathrm{kWp}$ and a battery energy storage system with a capacity of $5.4 \mathrm{kWh}$. Their test results showed that there was a $28 \%$ loss in the performance ratio of the system and further testing and evaluation were required. Wen $\mathrm{S}$ and Lan $\mathrm{H}$ et al [22-23] proposed a PV/diesel/energy storage system (ESS) ship's power system, which used an interval optimization algorithm and particle swarm optimization algorithm to ascertain the optimal size of a hybrid power system. Japan's Kokusho T [24] proposed a Sailing Solar-Cell Raft Project, which was supposed to develop a large windsailing solar cell raft that could produce $8 \mathrm{kwh} / \mathrm{m}^{2} /$ day of solar energy when the weather was good. Finally, Kyoung-Jun Lee et al. [25] designed a solar PV system using the standalone mode and used a cruise ship, whose displacement was $1.154 \mathrm{t}$, as the research object. The maximum peak power of the solar energy was calculated to be $3.2 \mathrm{~kW}$.

Most of the above-mentioned hybrid systems were based on boats, while designs and applications that are based on large scale vessels are rare. Even in a small number of cases when there were designs for large ships, the related solar and battery capacities were relatively small. In addition, the results relating to energy conservation and the reduction of emissions were only based on theoretical analysis and simulation, and any experimental verification was usually lacking.

Against this background, in 2013, the Wuhan University of Technology undertook a high-tech marine scientific research project on behalf of the Ministry of Industry and Information Technology. A unified grid-tied/stand-alone integrated solar PV system, with 
107 a peak power of $143 \mathrm{~kW}$, was designed, which had a built-in $652.8 \mathrm{kWh}$ lithium ion

108 battery storage system. In March 2014, it was installed in an actual 5000-vehicle space

109 PCTC, the "COSCO Tengfei", and put into operation. This ship was the world's first large-

110 scale cargo ship to use solar energy, and it also has the world's largest solar installation

111 area. Although the "COSCO Tengfei" has been in operation since March 2014, the PV

112 system and energy storage system on board are still in a good condition and to date, no

113 failures have occurred.

114 The main contribution of this paper is the design of a hybrid power system consisting of

115 solar energy, diesel generators, batteries, inverters, a battery management system (BMS),

116 and energy management system (EMS), based on the existing power system of the

117 "COSCO Tengfei". The energy saving and emission reduction effect of the solar PV

118 system is verified through an experimental test on the actual ship. The proposed hybrid

119 system will hopefully provide guidance for the future design of solar ships. It also will

120 lead to the conservation of energy and environmental protection. In addition, the solar

121 hybrid power system design scheme in this paper has broad application prospects for

122 various types of energy storage power plants, small and medium-sized PV grid-connected

123 power stations and microgrids.

124 The paper is organized as follows. Section 2 introduces the parameters of the research

125 object, and discusses the configuration and operation modes of the solar hybrid system.

126 Section 3 discusses the experimental results of tests conducted on the solar ship. Section 4 
127 analyzes the energy-saving and emission reduction effects of the solar energy system.

128 Conclusions are drawn in Section 5.

130 The "COSCO Tengfei" is a ship belonging to COSCO Shipping Co., Ltd. It is an ocean-

131 going ship built in 2011, which has parking spaces for 5000 vehicles. The ship is

132 classified in the China Ships Classification Society and flies the flag of Panama, as shown

133 in Figure 1.

134 The ship has a total length of $182.80 \mathrm{~m}$, a profile width of $32.20 \mathrm{~m}$, a depth of $14.95 \mathrm{~m}$,

135 a design draught of $8.40 \mathrm{~m}$, a structural draught of $9.40 \mathrm{~m}$, a design speed of $20.20 \mathrm{kn}$, and

136 a cruising range of 20,000 nautical miles. The technical parameters of the ship are listed in

137 Table 1.

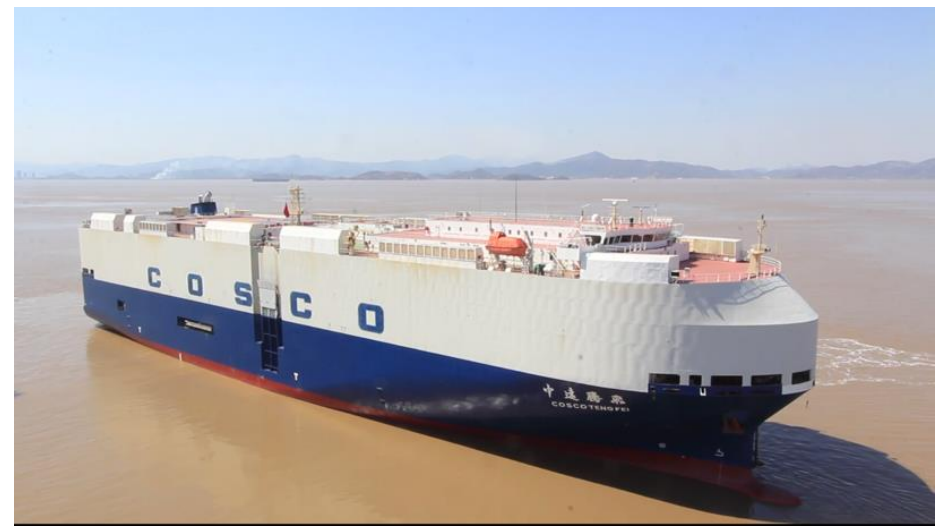

Figure 1 The "COSCO Tengfei"

Table 1 The basic parameters of the "COSCO Tengfei"

\begin{tabular}{llll}
\hline Type length & $182.80 \mathrm{~m}$ & Parking spaces & 5000 \\
Type width & $32.20 \mathrm{~m}$ & Main machine & 1 set, $14520 \mathrm{~kW}$ \\
Depth & $14.95 \mathrm{~m}$ & Generator & $1020 \mathrm{~kW} \times 2$ sets, $960 \mathrm{~kW} \times 1$ sets \\
Design draft & $8.40 \mathrm{~m}$ & Total weight & $14759.06 \mathrm{t}$ \\
Speed & $20.20 \mathrm{kn}$ & Cruising range & 20000 nautical miles \\
Displacement & $29150 \mathrm{t}$ & & \\
\hline
\end{tabular}


141 Based on the parameters of the "COSCO Tengfei" and the original power configuration,

142 a hybrid solar energy system was designed, as shown in Figure 2. The system consists of

143 solar panels, PV controllers, on/off-grid inverters, lithium-ion battery packs, a BMS,

144 diesel generator sets, transformers, and power distribution cabinets. The parameters of the

145 system's main components are shown in Table 2. The system's operation mode can be set

146 by the user to four different modes using a manual selection switch. These modes are now

147 outlined.

148 1. The off-grid operation mode. PV modules charge the battery through the PV

149 controller. The off-grid mode directly converts the PV and battery's direct current (DC)

150 voltage to a $450 \mathrm{~V}$ alternating current (AC) voltage. Then the AC voltage is stepped down

151 using a three-phase transformer, and directly supplied to the lights.

152 2. The grid-connected operation mode. Under the grid-connected mode, the energy

153 stored in the battery is delivered back to the grid. To prevent a current reverse impact on

154 the ship's synchronous generator, a set of anti-backflow devices is situated at the busbar.

155 3. The ship's grid powering mode under an insufficient output of solar energy. When

156 the PV system experiences a steep drop in output power and the battery energy is

157 insufficient to support the load, the bypass backup power is activated, and the ship's

158 original electrical power is used to provide energy to the lighting load.

159 4. The ship's grid powering mode under a PV system's fault condition. Under this 160 condition, a single pole double throw switch is switched to the original ship's power grid,

161 which provides energy to the lighting load. 


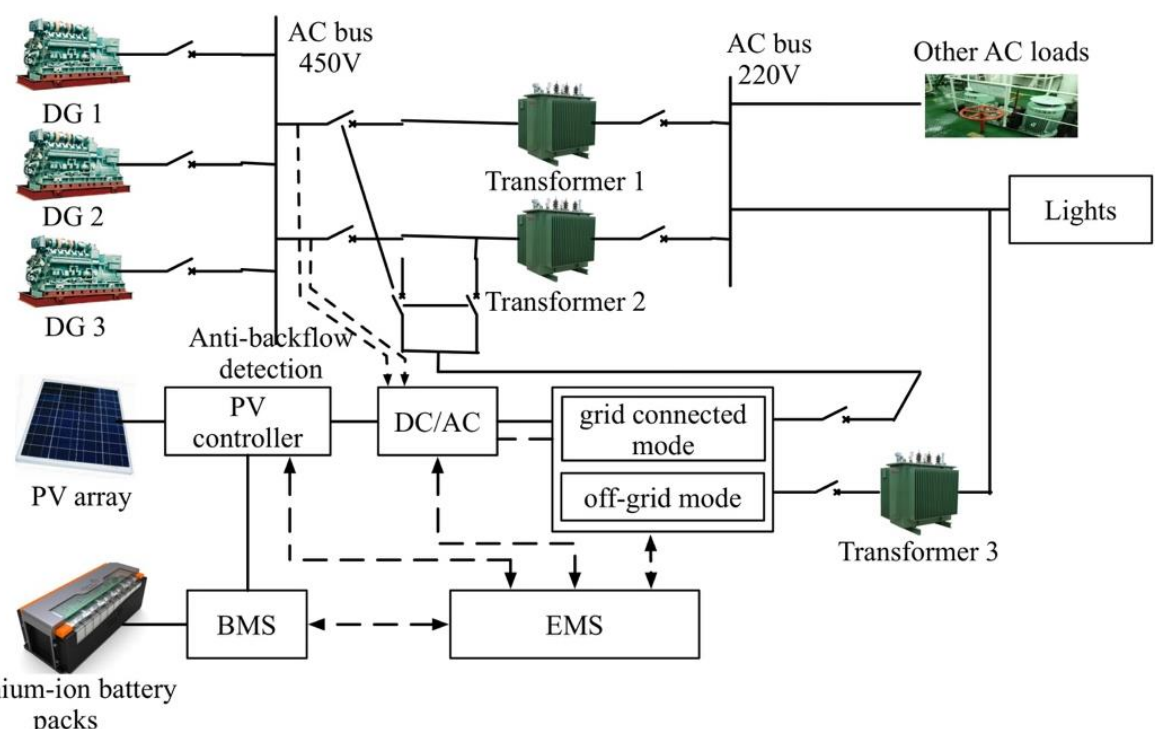

162 Lithium-ion battery

Figure 2 A block diagram of the solar hybrid system

Table 2 The main component parameters of the hybrid power system

\begin{tabular}{|c|c|c|c|c|c|c|}
\hline \multicolumn{7}{|c|}{ Solar system } \\
\hline $\begin{array}{c}\text { String } \\
\text { relationship }\end{array}$ & Total Power & Solar cell number & $\begin{array}{c}\text { Series open } \\
\text { circuit }\end{array}$ & $\begin{array}{c}\text { Short circuit } \\
\text { current }\end{array}$ & $\begin{array}{c}\text { Series peak } \\
\text { voltage }\end{array}$ & $\begin{array}{c}\text { Parallel peak } \\
\text { current }\end{array}$ \\
\hline $\begin{array}{c}18 \text { in series } \\
30 \text { in parallel } \\
\end{array}$ & $143 \mathrm{~kW}$ & 540 pieces & $702 \mathrm{~V}$ & $267.9 \mathrm{~A}$ & $558 \mathrm{~V}$ & $256.5 \mathrm{~A}$ \\
\hline \multicolumn{7}{|c|}{ Battery system } \\
\hline $\begin{array}{c}\text { String } \\
\text { relationship }\end{array}$ & $\begin{array}{c}\text { Rated output } \\
\text { voltage }\end{array}$ & $\begin{array}{l}\text { Overcharge } \\
\text { protection }\end{array}$ & $\begin{array}{l}\text { Over discharge } \\
\text { recovery voltage }\end{array}$ & $\begin{array}{c}\text { Maximum } \\
\text { capacity }\end{array}$ & \multicolumn{2}{|c|}{ Rated working capacity } \\
\hline $\begin{array}{l}120 \text { in series } \\
17 \text { in parallel } \\
\end{array}$ & $384 \mathrm{~V}$ & $438 \mathrm{~V}$ & $300 \mathrm{~V}$ & $734.4 \mathrm{kWh}$ & \multicolumn{2}{|c|}{$652.8 \mathrm{kWh}$} \\
\hline \multicolumn{7}{|c|}{ On/off inverter } \\
\hline \multirow{2}{*}{$\begin{array}{l}\text { Off-grid } \\
\text { mode }\end{array}$} & $\begin{array}{l}\text { Maximum DC } \\
\text { input power }\end{array}$ & $\begin{array}{l}\text { Maximum DC } \\
\text { input open circuit } \\
\text { voltage } \\
\end{array}$ & $\begin{array}{l}\text { Input voltage } \\
\text { range }\end{array}$ & $\begin{array}{c}\text { Rated AC } \\
\text { output } \\
\text { power } \\
\end{array}$ & Power factor & $\begin{array}{l}\text { Maximum } \\
\text { efficiency }\end{array}$ \\
\hline & $160 \mathrm{kWp}$ & $900 \mathrm{Vdc}$ & $300 \mathrm{Vdc}-780 \mathrm{Vdc}$ & $50 \mathrm{~kW}$ & $\begin{array}{l}>0.99 \text { (at } \\
\text { rated } \\
\text { power) }\end{array}$ & $95 \%$ \\
\hline \multirow{2}{*}{$\begin{array}{l}\text { Grid- } \\
\text { connected } \\
\text { mode }\end{array}$} & $\begin{array}{l}\text { Maximum DC } \\
\text { input power }\end{array}$ & $\begin{array}{c}\text { Maximum DC } \\
\text { input open circuit } \\
\text { voltage } \\
\end{array}$ & $\begin{array}{l}\text { Input voltage } \\
\text { range }\end{array}$ & $\begin{array}{c}\text { Rated AC } \\
\text { output } \\
\text { power } \\
\end{array}$ & Power factor & $\begin{array}{l}\text { Maximum } \\
\text { efficiency }\end{array}$ \\
\hline & $160 \mathrm{kWp}$ & $900 \mathrm{Vdc}$ & $300 \mathrm{Vdc}-780 \mathrm{Vdc}$ & $150 \mathrm{~kW}$ & $\begin{array}{l}>0.99 \text { (at } \\
\text { rated } \\
\text { power) }\end{array}$ & $95 \%$ \\
\hline \multicolumn{7}{|c|}{ Diesel generator } \\
\hline Model & $\begin{array}{l}\text { Calibration } \\
\text { power }\end{array}$ & Calibration speed & Fuel grade & \multicolumn{2}{|c|}{ Generator model } & $\begin{array}{c}\text { Generator } \\
\text { power }\end{array}$ \\
\hline 6N21AL-GV & $1020 \mathrm{~kW}$ & $900 \mathrm{r} / \mathrm{min}$ & $380 \mathrm{cst}$ & \multicolumn{2}{|c|}{ HTCT506-84R/2 } & $960 \mathrm{~kW}$ \\
\hline
\end{tabular}

\subsection{The solar PV system}

The "COSCO Tengfei" has a total of 14 decks, of which the 1st-3rd floors are used for

167 the ship's equipment, such as cabins, ballast water and anchor chains. The 3rd-12th floors 

are crew living areas and the ship's control area. According to the ship's actual measurements, the uncovered area of the "COSCO Tengfei's" upper deck is not more

171 than $1700 \mathrm{~m}^{2}$ and can be divided into 7 sections (as shown in Figures 3-4). The 1\# zone is the front of the ship's bridge, with an area of $180 \mathrm{~m}^{2}$; the $2 \#$ zone is the top deck of the 173 ship's bridge, with an area of $90 \mathrm{~m}^{2}$; the $3 \#$ zone is the U-shaped zone of the bridge's 174 deck with an area of $436 \mathrm{~m}^{2}$; and the 4\# zone is the emergency generator room and the top

175 of the $\mathrm{CO}^{2}$ room in the middle of the ship (number 4\#). It is approximately $100 \mathrm{~m}^{2}$, and a 176 back-up area of approximately $80 \mathrm{~m}^{2}$ is set beside the basketball court next to this area.

177 The 5\# zone is the rear area of the helicopter landing platform in the ship's middle section,

178 with an area of $140 \mathrm{~m}^{2}$; the $6 \#$ zone is the ship's tail area which is $240 \mathrm{~m}^{2}$, with $60 \mathrm{~m}^{2}$ of 179 spare space set near it; and the $7 \#$ zone consists of a $300 \mathrm{~m}^{2}$ back-up area on the 180 walkways on both sides of the ship. Taking into account the driving specifications and 181 safety requirements, as well as the arrangement of the channels between the solar arrays,

182 the actual area available for the installation of solar panels is approximately $1300 \mathrm{~m}^{2}$.

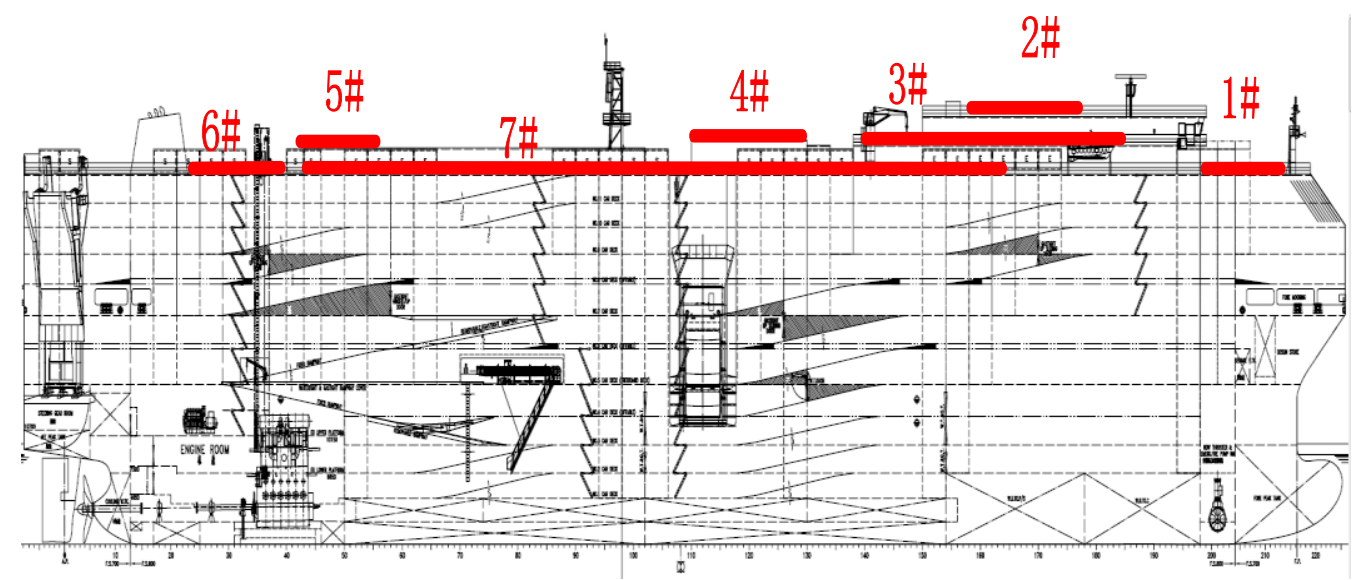

Figure 3 The vertical section of the area that can be used to arrange the PV panels 

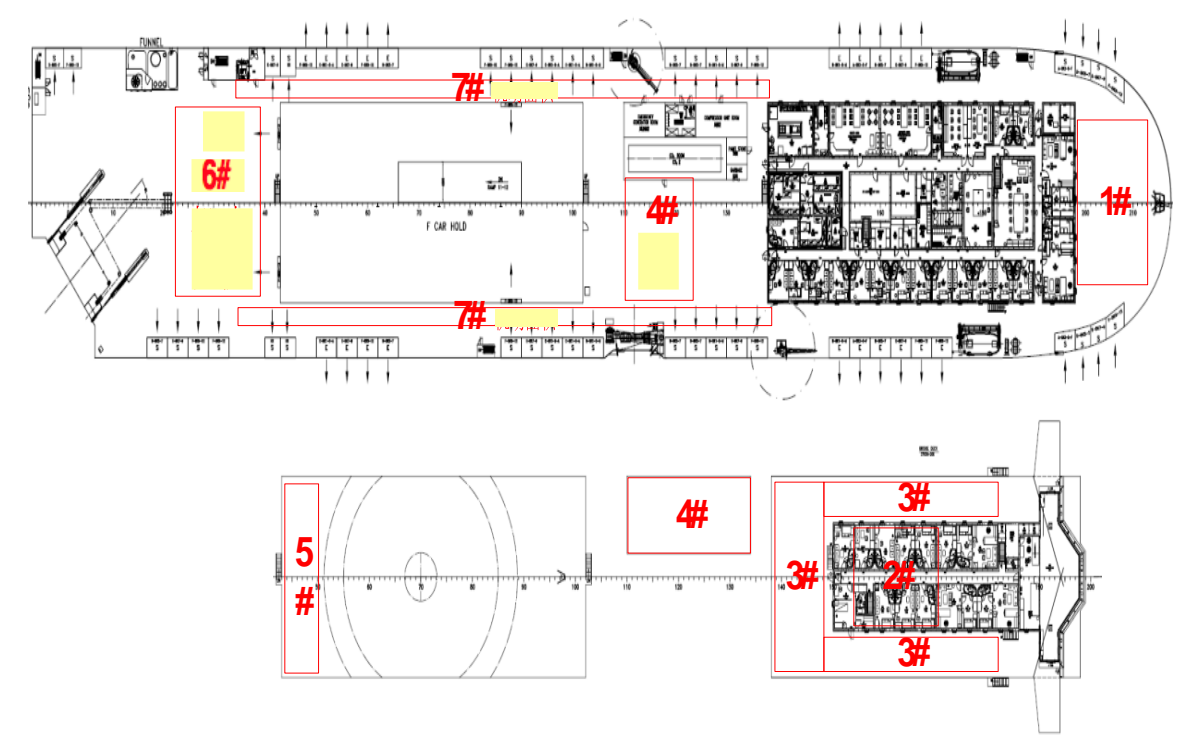

185

186

187

188

189

190

191

192

193

194

195

196

197

198

Figure 4 The top view of the main deck of the solar PV panel area

The solar PV system uses a PANDA 60 Cell $40 \mathrm{~mm}$ series monocrystalline silicon solar panel produced by Yingli Green Energy Holdings Co., Ltd., whose model number is YL265C-30b. The peak power under standard test conditions is $265 \mathrm{~W}$, and its size is $1650 \mathrm{~mm} \times 990 \mathrm{~mm} \times 40 \mathrm{~mm}$, with a weight of $19.1 \mathrm{~kg}$.

Based on the $140 \mathrm{~kW}$ total capacity design and standard irradiation conditions (1000 $\mathrm{W} / \mathrm{m}^{2}$, panel temperature $20^{\circ} \mathrm{C}$ ), by using 18 solar panels in series for a string and 30 strings in parallel, a total number of 540 solar panels are required. After considering the set-up of the maintenance aisle, the total installation area is approximately $1050 \mathrm{~m}^{2}$. The solar module mounting bracket is customized according to the ocean ship's anti-corrosion protection grade. A galvanized steel material bracket is used and covered with high quality anti-corrosion paint. Riveting is used to secure the ship's hook, and the riveted components are also covered with anti-corrosion paint. 
210 which can achieve anti-islanding control. An overview of the solar PV system installation

211 is shown in Figure 5.

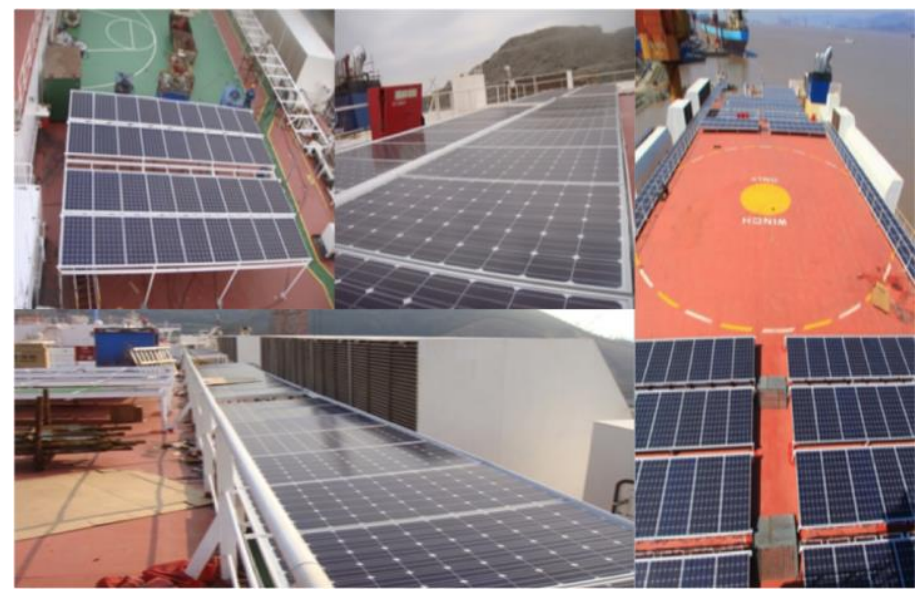

\section{$214 \quad 2.2$ The battery energy storage system}


216 batteries. This battery is produced by China Shipbuilding Heavy Industry (Beijing)

217 Technology Co., Ltd. and has a weight of $20 \mathrm{~kg}$. The 120 battery cells are connected in

218 series as a string and 17 strings are connected in parallel to formulate a battery energy

219 storage system with a total capacity of $652.8 \mathrm{kWh}$. The PACK unit of the energy storage

220 system is designed according to the power requirements of the actual ship, while the heat

221 dissipation and protection under high temperatures are fully taken into consideration. The

222 BMS is used to manage the battery pack. The actual installation photo of the battery

223 system is shown in Figure 6.

224

225

226

227

228

229

230

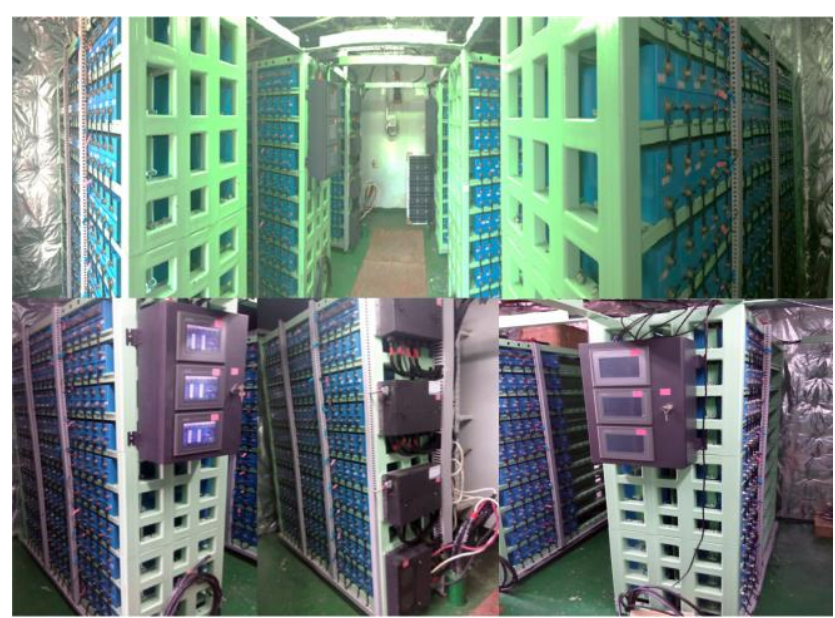

Figure 6 The battery system installation on the actual ship

\subsection{The diesel generators and loads}

There are three diesel generators installed on the "COSCO Tengfei", which are produced by YANMAR. Two of them are 1020kW 6N21AL-GV diesel engines, while the other is a $960 \mathrm{~kW} 6$ N21AL-UV diesel engine. Figure 7 shows a $1020 \mathrm{~kW} 3 \#$ diesel generator. 


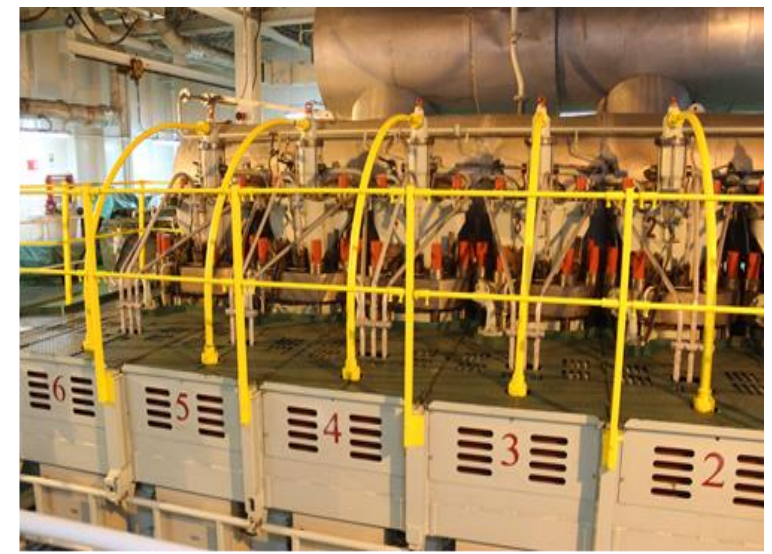

Figure 7 A 3\# diesel generator

The solar PV system has stand-alone and grid-connected operational modes. In the

floors. The lighting is provided by 1220 18W LED lamps and 376 40W ordinary

236 fluorescent lamps. The cargo deck is lit for 24 hours and the total power consumption is

$237888 \mathrm{kWh}$. In the grid-connected mode, the solar energy will be injected into the ship's

238 power grid system to produce its maximum power level, with an output power of up to $239143 \mathrm{~kW}$.

\subsection{The EMS}

The EMS consists of four modules: data input and process, display, output and control

242 which are shown in figure 8. The EMS reads the PV voltage and current of the solar system

243 and the voltage, current, frequency, power and efficiency of the inverter from the solar

244 charging controller, the BMS, the inverter and the ship power station monitoring system

245 through a RS485 communication interface. The voltage, current, radiation intensity, panel

246 ambient temperature and cabin temperature of the $\mathrm{N}$ sets of solar panels are read through an

247 analog input module. The connection state of the inverter output side contactor is read via the 
248 digital input module. The received data is processed by a data processing unit, and then

249 displayed on a monitor. The system controls the output of each power source according to the

250 load variation, the instantaneous power generation of solar energy, and the state of charge

251 (SOC) of the battery pack through a pre-designed EMS. Since the solar controller, inverter,

252 BMS and ship's power station monitoring system all have self-protection functions, they will

253 automatically take protective measures when encountering any faults. The safety monitoring

254 device can receive the fault data through a RS485 communication interface and issue an

255 alarm accordingly. In the meantime, it controls the contactor located at the output of the grid-

256 connected inverter, which can be disconnected from the entire system. To facilitate historical

257 data acquisition and failure analysis, all the collected data can be stored in the host computer

258 and the system can also realize remote data transmissions through a $3 \mathrm{G}$ network. In order to

259 avoid the communication signal from being interfered with distance, various metals and

260 electronic equipment inside the cabin, the industrial computer and the $3 \mathrm{G}$ wireless router are

261 placed inside the cabin on the side of the ship. The communication antenna extends out of the

262 box to the outside of the cabin, and is attached to the iron wall through its bottom magnet.

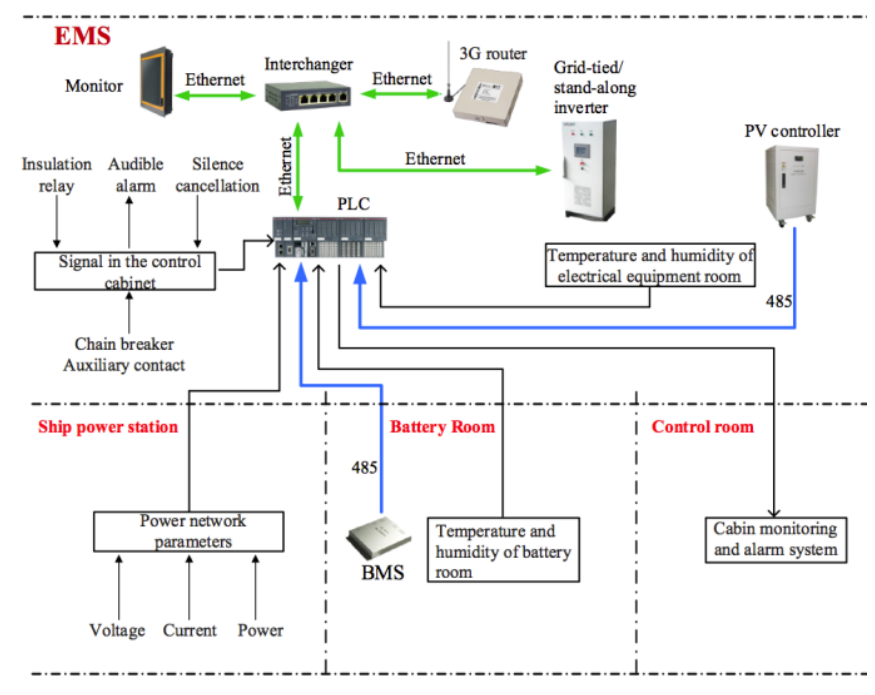




\section{The experimental result of the tests conducted on the solar-powered} hybrid ship

When ships arrive or depart from a harbor (including the time they are docked), due to the frequent switching of electrical equipment, the ship's load may change between $250 \mathrm{~kW}$ and $600 \mathrm{~kW}$, while the engine is generally not allowed to use more than $75 \%$ of the rated power. Therefore, to ensure the safety of the ship during its arrival or departure, two auxiliary generators work simultaneously. The total load of the ship during normal sailing is around $600 \mathrm{~kW}$, and only one auxiliary generator is in operation.

After completing the installation and debugging of the solar PV system and the

274 battery energy storage system, the research team conducted a test on the operation

275 parameters of the actual ship's hybrid power system. In which, tests for $\mathrm{CO}_{2}$ and some 276 other gases adopted the SEMTECH-DS exhaust gas analysis system (as shown in Figure

277 9). The SEMTECH-DS mainly performs $\mathrm{CO}_{2}$ detection by a non-dispersive infrared 278 analysis method with an accuracy of $\pm 0.1 \%$. The system sampling probe is installed at the 279 end of the diesel engine with at least a distance of 10 exhaust pipe diameters, but at the 280 same time at least $0.5 \mathrm{~m}$ or 3 times the exhaust pipe diameter (whichever is greater) above

281 the outlet of the exhaust system (see figure 9(a)). During the measurement process, the 282 power system data can be directly obtained by the EMS. Each measurement point is 283 assessed after the diesel engine reaches a stable operation mode, and the measurement 284 time is $10 \mathrm{~min}$. At each measurement point, after the system is stable for 5 minutes, 
samples are continuously taken from the diesel engine exhaust gas. Then, the

286 measurement data is stored in the data acquisition system. The sampling rate of the

287 SEMTECH-DS exhaust gas analysis system is set to three times per minute. The average

288 value of the $\mathrm{CO}_{2}$ concentration during this acquisition period is taken as the effective

289 value of the $\mathrm{CO}_{2}$ emission at the measurement point.

290 The test took place on March 29, 2016 from 11:05 am to 19:20 pm. The power generation

291 data acquisition experiments were performed in the grid-connected mode under both the

292 arrival/departure and normal sailing conditions.

293

294

295

296

297

298

299

300

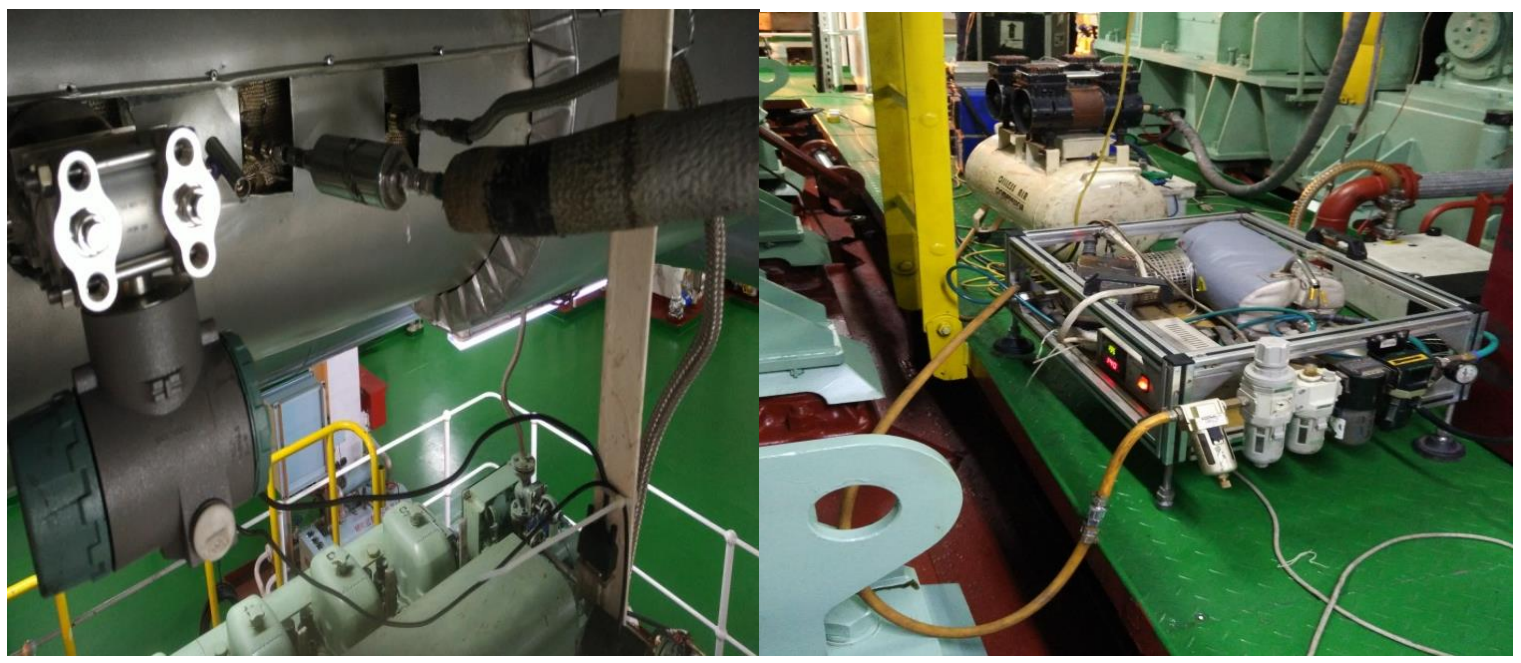

(a) The sampling probe installation position

(b) The data acquisition box

Figure 9 The SEMTECH-DS exhaust gas analysis system

Figure 10 shows the power curve of the solar and diesel generators and loads during arrival/departure. It can be seen from Figure 10 that the load switches frequently between $250 \mathrm{~kW}$ and $600 \mathrm{~kW}$, due to the frequent operations and the switching of electrical equipment when arriving or leaving the port. The output power of the solar energy also fluctuates during this period. This is because the direction of the ship changes when it 
301 arrives or departs from a port, leading to an intense change in the solar radiation levels of

302 the solar panels. Figure 11 shows the power curve of the solar and diesel generators and

303 loads under normal sailing conditions. When the ship is sailing normally, the ship's load

304 only changes within a small range of about $600 \mathrm{~kW}$, and the output power of the solar 305 energy changes slowly with the change of the sunlight's intensity.

306

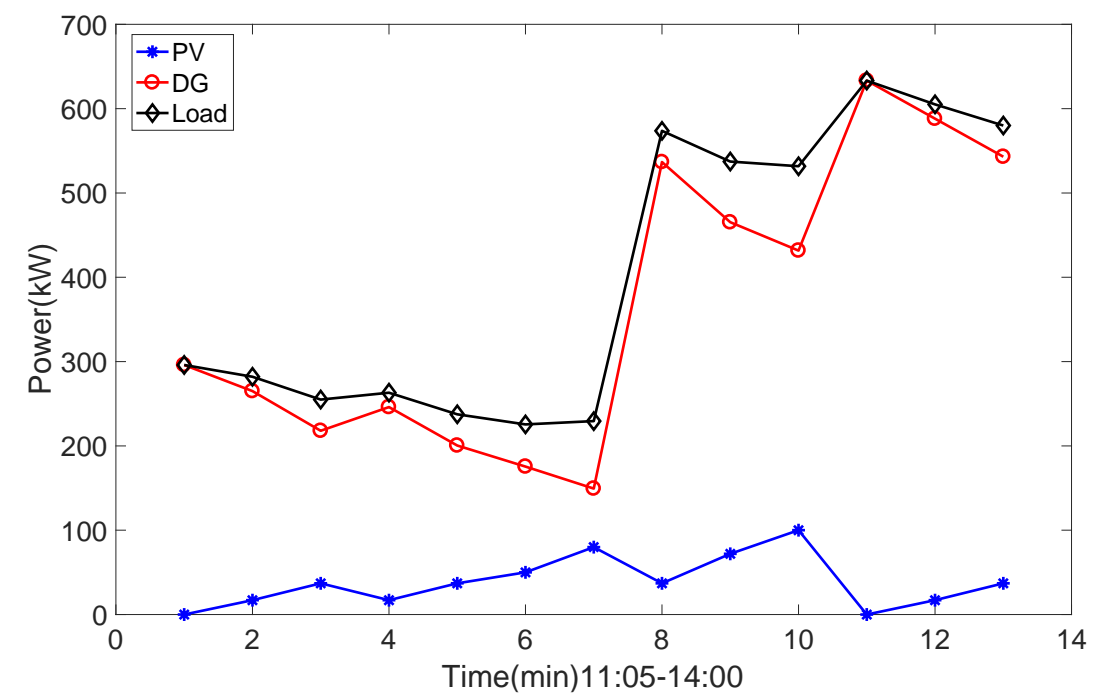

307

Figure 10 The experimental data during arrival/departure

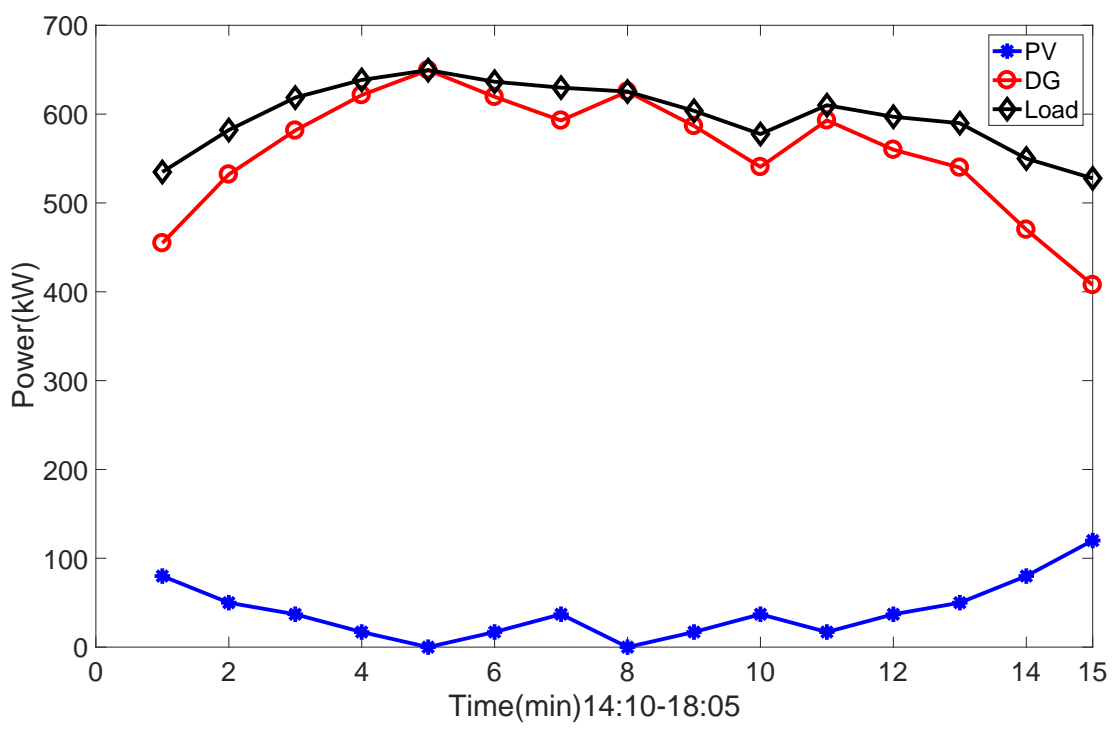

Figure 11 The experimental data during normal sailing 
311 the operating parameters of the hybrid power system under various operating conditions

312 were being obtained. Figure 12 shows the relationship between fuel consumption, solar

313 power and load power during arrival/departure. It can be clearly seen from figure 12 that

314 when the ship's load power is low and the solar PV system power generation is between

$31550-80 \mathrm{~kW}$, the ship's fuel consumption is low. As the demand for the ship's load increases,

316 so does its fuel consumption. However, when the ship's load is constant, its fuel

317 consumption first decreases with the increasing solar power and then increases slightly.

318 To illustrate the problem more clearly, the defined PV penetration is the ratio of the solar

319 power integrated with the grid power and the ship's load. Figures 13 and 14 show the

320 relationship between diesel fuel consumption and PV penetration during the

321 arrival/departure process when the load is $300 \mathrm{~kW}$ and $600 \mathrm{~kW}$ respectively. When the

322 load demand is $300 \mathrm{~kW}$, the PV penetration is below $20 \%$, and the fuel consumption

323 decreases with the increase of the PV penetration. When the PV penetration is between

$32420-30 \%$, that is, when the power is between $60-90 \mathrm{~kW}$, the ship's fuel consumption is the

325 lowest. When the proportion of solar energy is greater than 30\%, the ship's fuel

326 consumption will increase slowly. Similarly, when the load demand is $600 \mathrm{~kW}$, the PV

327 penetration is below $12 \%$, and the fuel consumption is reduced with the increase of the

328 PV penetration. When the PV penetration is between $12-15 \%$, that is, when the power is

329 between $72-90 \mathrm{~kW}$, the ship's fuel consumption is the lowest. The reason for this is that

330 the maximum fuel efficiency of the diesel engine occurs between $60 \%$ and $100 \%$ of the 
331 load. During arrival/departure, the two diesel engines provide electricity to the ship, and

332 the diesel engines are all under a low load. Figure 15 shows the relationship between

333 specific fuel consumption and the power of the diesel engine. It can be seen that under

334 low load conditions, the specific fuel consumption of the diesel engine will increase

335 rapidly with the decrease of the load, resulting in the phenomenon that the fuel

336 consumption of the diesel engine increases while the power is reduced.

337
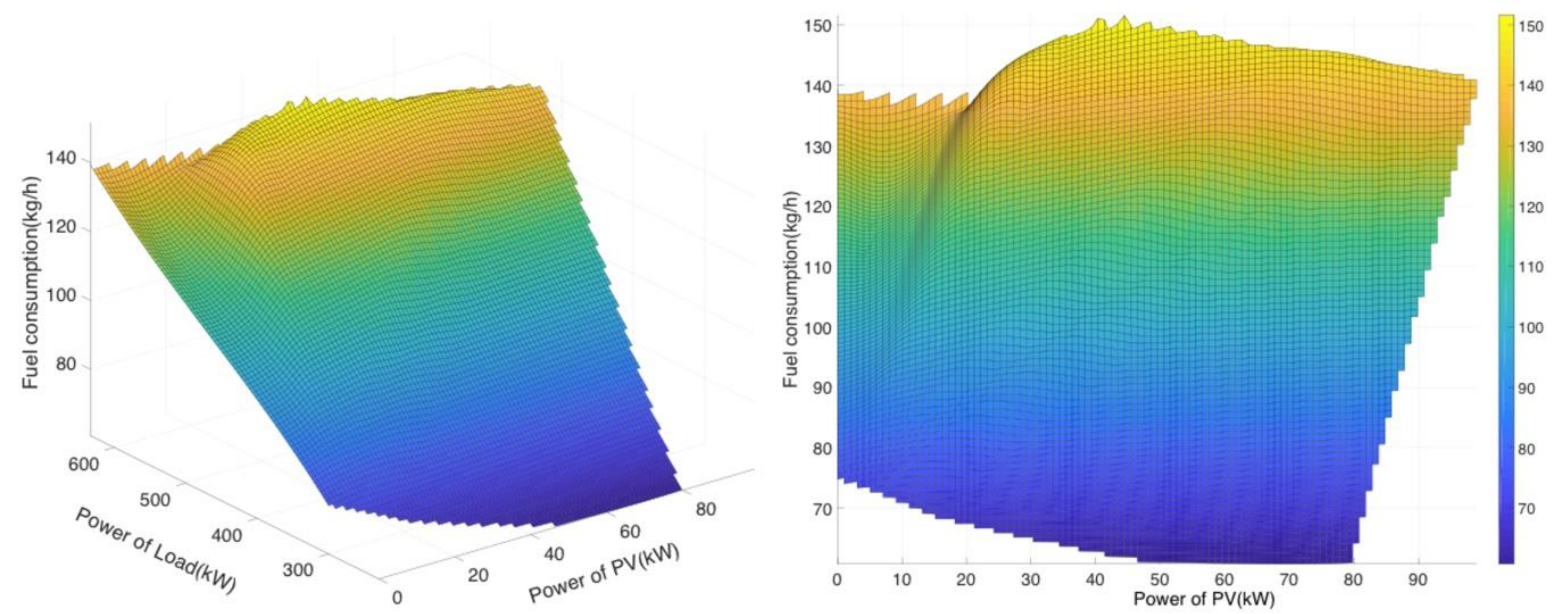

338 Figure 12 The fuel consumption vs. the PV and load power changes during

arrival/departure

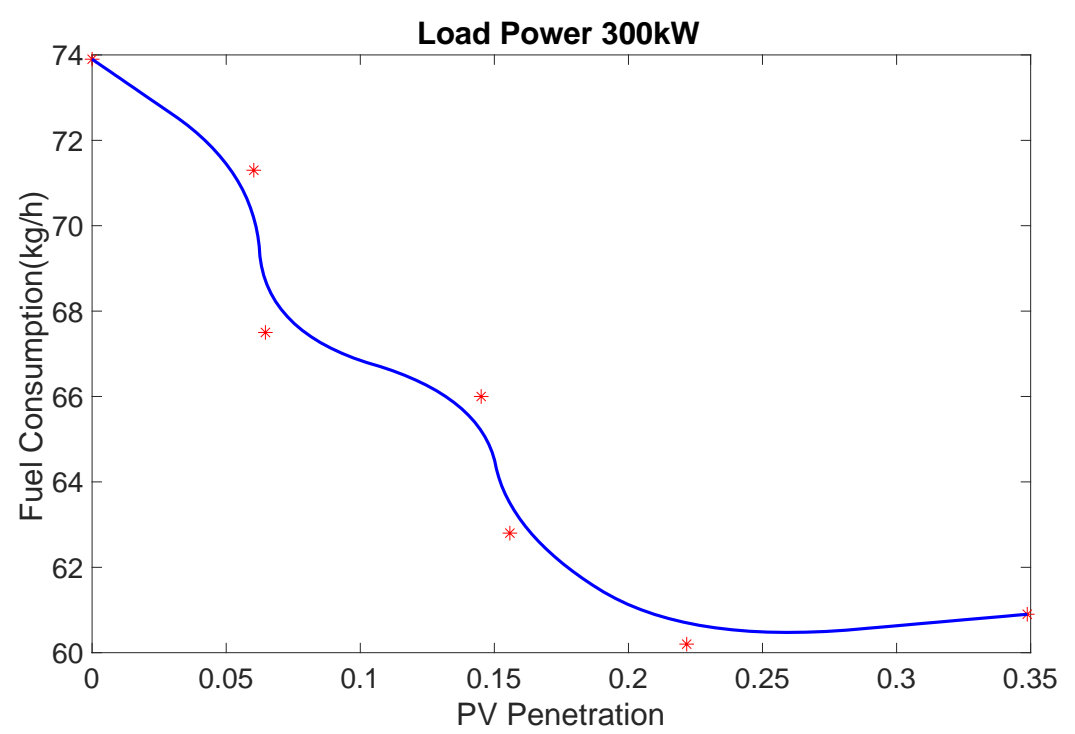




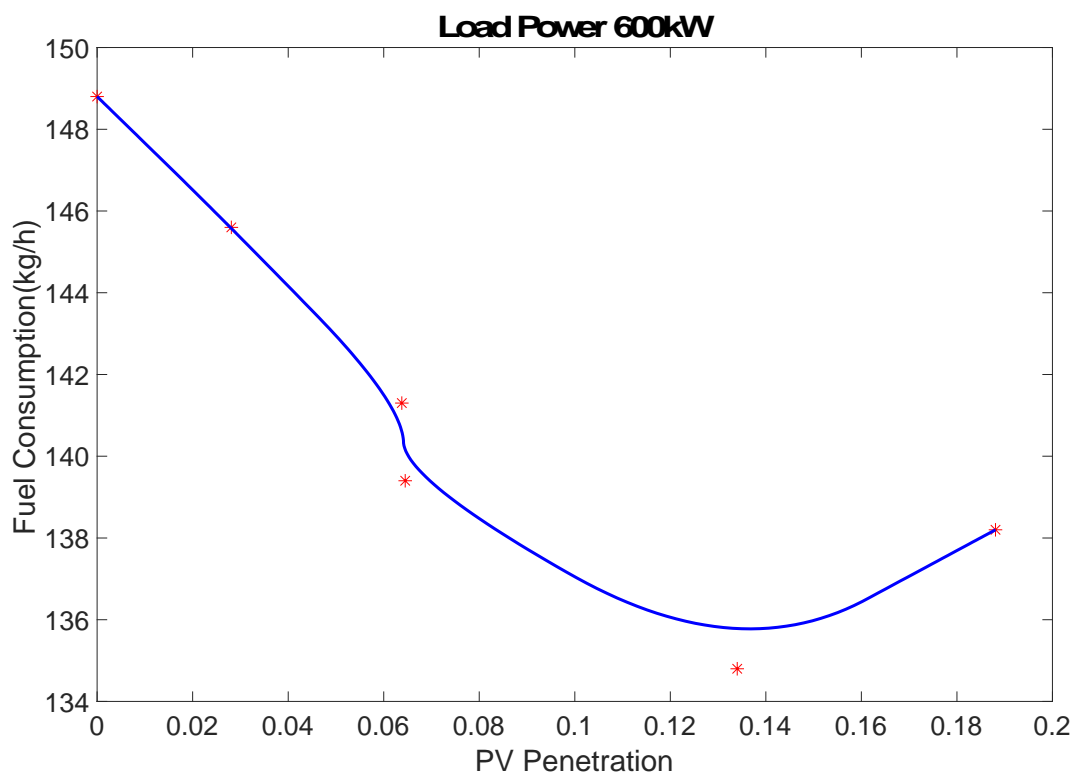

Figure 14 The relationship between fuel consumption and PV penetration during

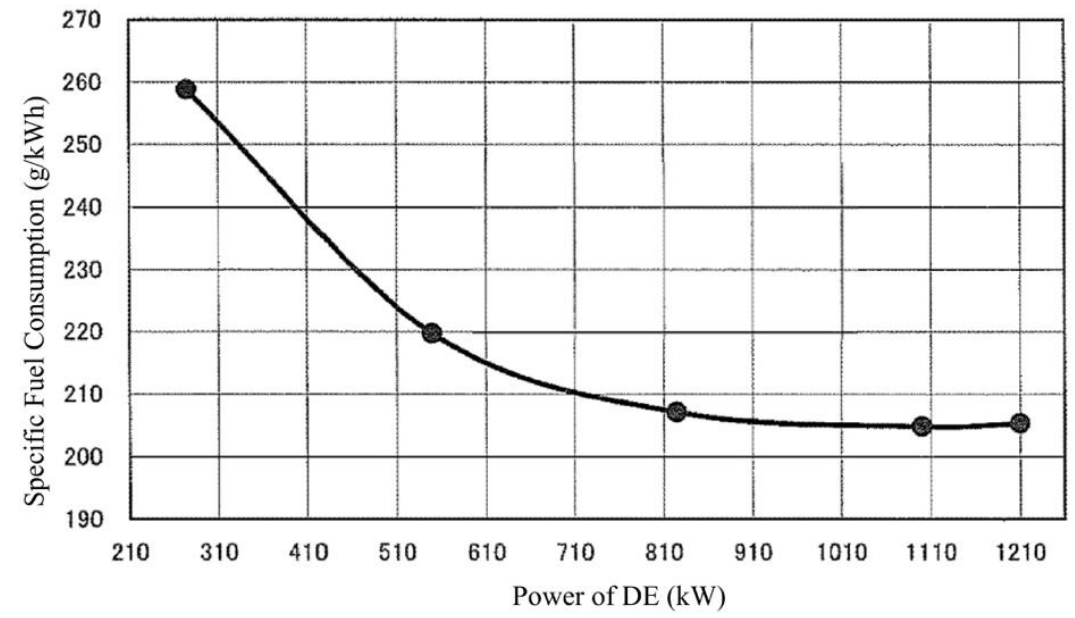

347 Figure 15 The relationship between specific fuel consumption and the power of the diesel engine generated and the load demand during normal navigation conditions. As can be seen, 
351 when the ship's load demand is low and the PV system power is $120 \mathrm{~kW}$, the fuel

352 consumption is minimal. As the demand for the ship's load increases, so does the fuel

353 consumption. When the ship's load is constant, the ship's fuel consumption decreases as

354 the solar power increases. Figure 17 displays the curve of the change between the fuel

355 consumption and the PV penetration when the ship's load demand is $600 \mathrm{~kW}$ during

356 normal sailing conditions. It can be seen that the ship's fuel consumption gradually

357 decreases as the PV penetration increases. This is because when the ship is sailing

358 normally, its load is basically around $600 \mathrm{~kW}$. A diesel generator provides electrical

359 energy for the ship and basically operates within an economic scope. Therefore, the fuel

360 consumption varies little with the load (see figure 15); thus when the power is reduced the

361 fuel consumption will also reduce.

362
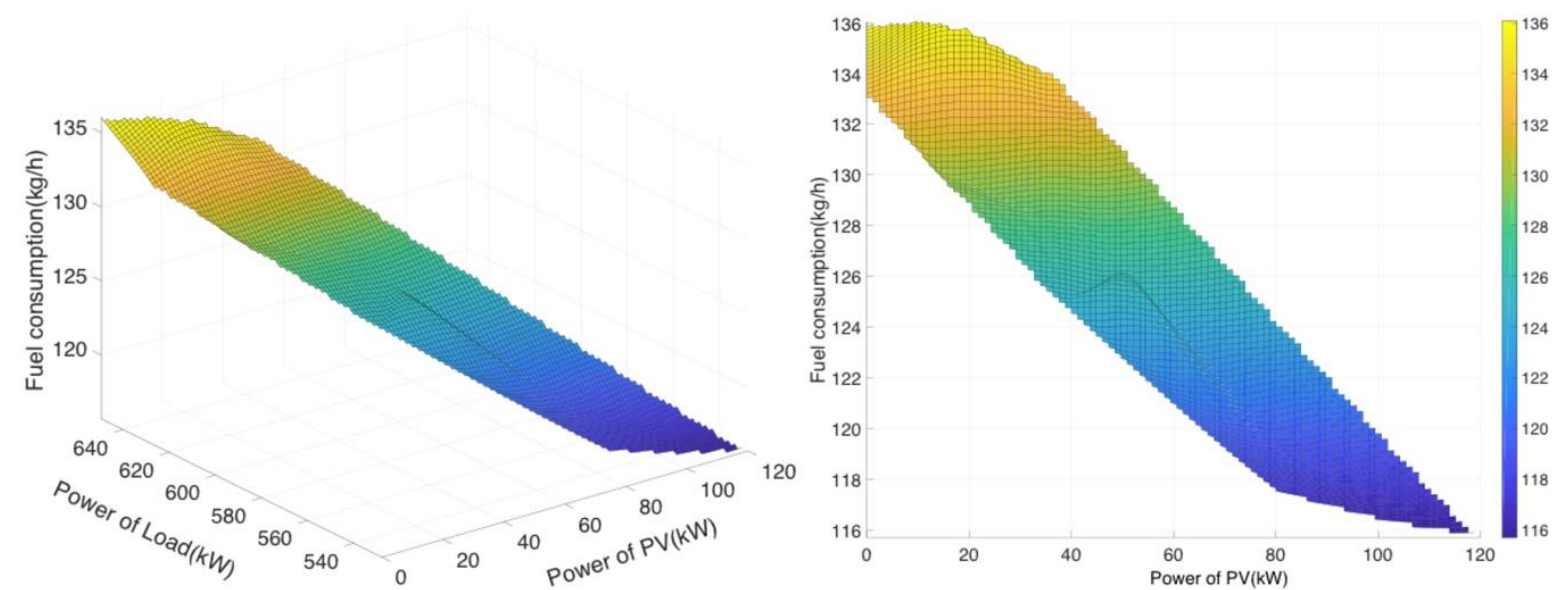

363 Figure 16 The fuel consumption under a function of PV and load power during normal 


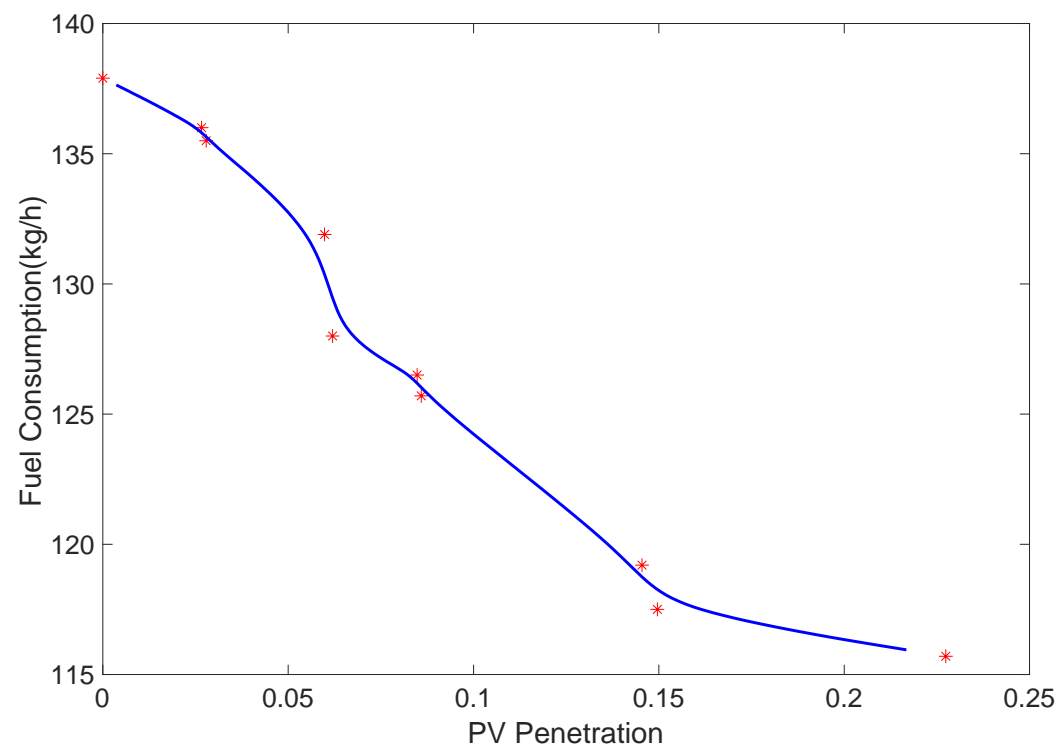

366 Figure 17 The relationship between fuel consumption and PV penetration during normal sailing $(\mathrm{load}=600 \mathrm{~kW})$

\section{An analysis of the energy saving and emission reduction of solar}

\section{hybrid ships}

The "COSCO Tengfei" operates for an average of 365 days per year. Its routes are mainly: China (Tianjin, Shanghai, Guangzhou) - Brazil (Victoria) - Nigeria - Germany

372 (Hamburg) - Belgium - Netherlands (Rotterdam) - Suez Canal - India - Singapore - China; 373 about 11 ports, a total of 55 days in harbor and 310 days of normal sailing. Through a 374 statistical analysis of the weather information on the route, the solar PV system can work 375 for 292 days per year, which is $80 \%$ of the total operation time. More specifically, the 376 operation of the solar system in a harbor is about 44 days, while the operation of the solar 377 system during normal sailing is about 248 days. According to the time period in port or 378 during normal sailing, an average electricity load of $600 \mathrm{~kW}$ and $6 \mathrm{~h}$ of sunshine per day are assumed in order to calculate the effects of energy saving and emission reductions for 
one year. For the solar hybrid system proposed in this paper, since the diesel generator only

381 uses diesel as a fuel, the emitted $\mathrm{CO}_{2}$ is only generated by the diesel generator. During

$$
\begin{aligned}
Q_{\text {fuel }} & =\frac{24 \times 44 \times q_{0}}{10^{3}} \\
Q_{\text {fuel }} & =\frac{18 \times 44 \times q_{0}}{10^{3}}+\frac{6 \times 44 \times q}{10^{3}}
\end{aligned}
$$

$$
\begin{aligned}
& \text { when } P V_{\text {Penetration }}=0 \\
& \text { when } P V_{\text {Penetration }}>0
\end{aligned}
$$

- $\mathrm{CO}_{2}$ emissions

$$
\begin{array}{ll}
Q_{\mathrm{CO}_{2}}=\frac{3600 \times 24 \times 44 \times \mathrm{g}_{0}}{10^{6}} & \text { when } P V_{\text {Penetration }}=0 \\
Q_{\mathrm{CO}_{2}}=\frac{3600 \times 18 \times 44 \times g_{0}}{10^{6}}+\frac{3600 \times 6 \times 44 \times g}{10^{6}} & \text { whne } P V_{\text {Penetration }}>0
\end{array}
$$

(2) Normal Navigation period

$$
\text { - Fuel Consumption }
$$

$$
\begin{array}{ll}
Q_{\text {fuel }}=\frac{24 \times 248 \times q_{0}}{10^{3}} & \text { when } P V_{\text {Penetration }}=0 \\
Q_{\text {fuel }}=\frac{18 \times 248 \times q_{0}}{10^{3}}+\frac{6 \times 248 \times q}{10^{3}} & \text { when } P V_{\text {Penetration }}>0
\end{array}
$$

- $\mathrm{CO}_{2}$ emissions

$$
\begin{array}{ll}
Q_{\mathrm{CO}_{2}}=\frac{3600 \times 24 \times 248 \times g_{0}}{10^{6}} & \text { when } P V_{\text {Penetration }}=0 \\
Q_{\mathrm{CO}_{2}}=\frac{3600 \times 18 \times 248 \times g_{0}}{10^{6}}+\frac{3600 \times 6 \times 248 \times g}{10^{6}} & \text { when } P V_{\text {Penetration }}>0
\end{array}
$$

397 emission per unit time when the PV penetration is $0, g / s$; and $g$ is the $\mathrm{CO}_{2}$ emission per unit 

in Table 3.

Table 3 Fuel consumption and $\mathrm{CO}_{2}$ emissions under different PV penetrations

\begin{tabular}{|c|c|c|c|c|c|}
\hline \multicolumn{3}{|c|}{ Departure/Arrival } & \multicolumn{3}{c|}{ Normal Navigation } \\
\hline $\begin{array}{c}\text { PV } \\
\text { penetration }\end{array}$ & $\begin{array}{c}\text { Fuel Consumption } \\
\left(q_{0} / q, \mathrm{~kg} / \mathrm{h}\right)\end{array}$ & $\begin{array}{c}\mathrm{CO}_{2} \text { emission } \\
\text { rate }\left(g_{0} / g, g / s\right)\end{array}$ & $\begin{array}{c}\mathrm{PV} \\
\text { penetration }\end{array}$ & $\begin{array}{c}\text { Fuel Consumption } \\
\left(q_{0} / q, \mathrm{~kg} / \mathrm{h}\right)\end{array}$ & $\begin{array}{c}\mathrm{CO}_{2} \text { emission } \\
\text { rate }\left(g_{0} / g, g / s\right)\end{array}$ \\
\hline $0 \%$ & 148.8 & 116.38 & $0 \%$ & 137.9 & 114.8 \\
\hline $6.4 \%$ & 139.4 & 112.38 & $8.4 \%$ & 126.5 & 87.52 \\
\hline $13.4 \%$ & 134.8 & 98.48 & $14.5 \%$ & 119.2 & 80.52 \\
\hline $18.8 \%$ & 138.2 & 93.64 & $22.7 \%$ & 115.7 & 75.54 \\
\hline
\end{tabular}

403 emissions under different PV penetrations during the year, whilst the ship is in port, are 404 shown in Figure 18.

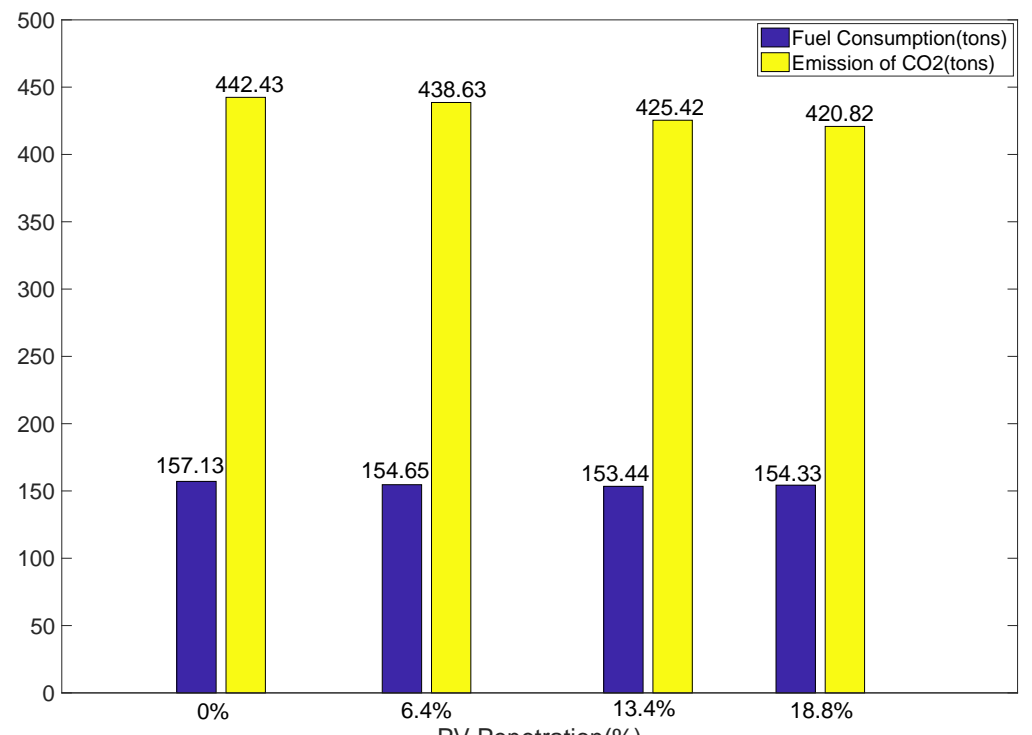

406 Figure 18 The $\mathrm{CO}_{2}$ emissions and fuel consumption with different $\mathrm{PV}$ penetrations in a year during arrival/departure

408 Based on the calculations, the energy saving and emission reduction effects of 409 different PV penetrations during the time of arrival/departure are shown in Table 4. When 410 the proportion of solar energy is $6.4 \%, 13.4 \%$ and $18.8 \%$, the ship can save $2.48 \mathrm{t}, 3.70 \mathrm{t}$ 
411 and $2.80 \mathrm{t}$ of fuel respectively, and reduce the $\mathrm{CO}_{2}$ emissions by $13.80 \mathrm{t}, 17.01 \mathrm{t}$ and

41221.61 t. Compared with the pure diesel generator system, the reduction of fuel

413 consumption will be $1.58 \%, 2.35 \%$ and $1.78 \%$ and the reduction of $\mathrm{CO}_{2}$ emissions is

$414 \quad 0.86 \%, 3.85 \%$ and $4.88 \%$ respectively.

415 Table 4 The energy saving and emission reduction results of different PV penetrations

416 during arrival/departure

\begin{tabular}{|c|c|c|c|c|c|c|}
\hline $\begin{array}{c}\text { PV } \\
\text { penetration }\end{array}$ & $\begin{array}{c}\text { Fuel } \\
\text { consumption } \\
\text { per year }(\mathrm{t})\end{array}$ & $\begin{array}{c}\mathrm{CO}_{2} \\
\text { emission } \\
\text { per year }(\mathrm{t})\end{array}$ & $\begin{array}{c}\text { Fuel } \\
\text { saving(t) }\end{array}$ & $\begin{array}{c}\text { Emission } \\
\text { reduction(t) }\end{array}$ & $\begin{array}{c}\text { Fuel saving } \\
\text { ratio\% }\end{array}$ & $\begin{array}{c}\text { Emission } \\
\text { reduction } \\
\text { ratio\% }\end{array}$ \\
\hline $0 \%$ & 157.13 & 442.43 & 0.00 & 0.00 & $0.00 \%$ & $0.00 \%$ \\
\hline $6.4 \%$ & 154.65 & 438.63 & 9.93 & 3.80 & $1.58 \%$ & $0.86 \%$ \\
\hline $13.4 \%$ & 153.44 & 425.42 & 14.78 & 17.01 & $2.35 \%$ & $3.85 \%$ \\
\hline $18.8 \%$ & 154.33 & 420.82 & 11.19 & 21.61 & $1.78 \%$ & $4.88 \%$ \\
\hline
\end{tabular}

417

418 The annual fuel consumption and $\mathrm{CO}_{2}$ emissions of ships with different

419 proportions of solar energy during normal navigation are shown in Figure 19. Based on

420 the calculations, the energy saving and emission reductions under different PV

421 penetrations during the ship's normal navigation period are shown in Table 5. When the

422 PV penetration is $8.157 \%, 14.5 \%$ and $22.7 \%$, the ship can save $16.96 \mathrm{t}, 27.83 \mathrm{t}$ and 33.03

$423 \mathrm{t}$ of fuel respectively, while reducing the $\mathrm{CO}_{2}$ emissions by $146.13 \mathrm{t}, 183.63 \mathrm{t}$ and $210.31 \mathrm{t}$.

424 Compared with the pure diesel generator, the reduction in fuel consumption is $2.07 \%$,

$4253.39 \%$ and $4.02 \%$, while the $\mathrm{CO}_{2}$ emissions are cut by $5.94 \%, 7.47 \%$ and $8.55 \%$

426 respectively. 


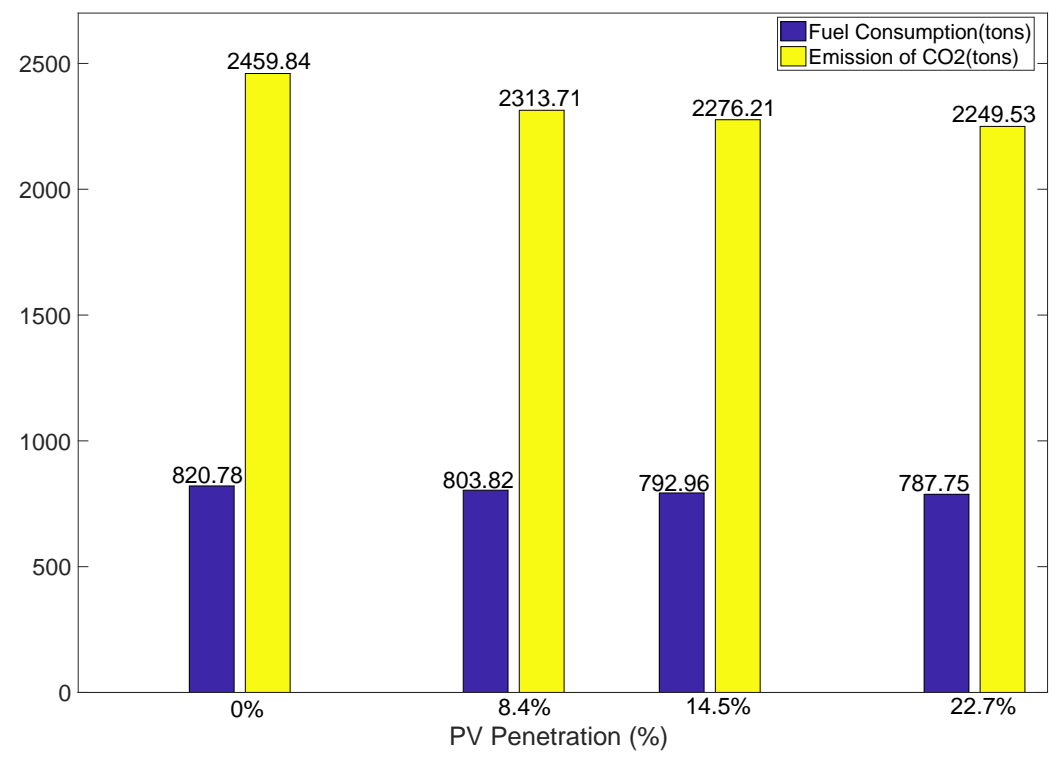

429 Figure 19 The $\mathrm{CO}_{2}$ emissions and fuel consumption under different PV penetrations in a year during normal sailing periods Table 5 The energy saving and emission reduction results under different PV penetrations during normal sailing periods

\begin{tabular}{|c|c|c|c|c|c|c|}
\hline $\begin{array}{c}\text { PV } \\
\text { penetration }\end{array}$ & $\begin{array}{c}\text { Fuel } \\
\text { consumption } \\
\text { per year }(\mathrm{t})\end{array}$ & $\begin{array}{c}\mathrm{CO}_{2} \text { emission } \\
\text { per year }(\mathrm{t})\end{array}$ & $\begin{array}{c}\text { Fuel } \\
\text { saving(t) }\end{array}$ & $\begin{array}{c}\text { Emission } \\
\text { reduction(t) }\end{array}$ & $\begin{array}{c}\text { Fuel saving } \\
\text { ratio \% }\end{array}$ & $\begin{array}{c}\text { Emission } \\
\text { reduction } \\
\text { ratio \% }\end{array}$ \\
\hline $0 \%$ & 820.78 & 2459.84 & 0 & 0 & $0.00 \%$ & $0.00 \%$ \\
\hline $8.4 \%$ & 803.82 & 2313.71 & 16.96 & 146.13 & $2.07 \%$ & $5.94 \%$ \\
\hline $14.5 \%$ & 792.96 & 2276.21 & 27.83 & 183.63 & $3.39 \%$ & $7.47 \%$ \\
\hline $22.7 \%$ & 787.75 & 2249.53 & 33.03 & 210.31 & $4.02 \%$ & $8.55 \%$ \\
\hline
\end{tabular}
In recent years, the prices of international crude oil have fluctuated greatly.

435 Therefore, in order to ensure the representativeness of the calculation results, the 436 historical average price of marine diesel oil (MDO) from 2014 to 2017 [26] is selected for 437 analysis when conducting an assessment of the economic benefits. The light fuel price is 438 calculated to be about $\$ 837.96 /$ ton. In an ideal case, the economic savings of fuel during one year for a ship would be: 


\section{Conclusions}

442 In this paper, a 5000-vehicle space PCTC named the "COSCO Tengfei" was 443 redesigned using a large-scale (peak power $143 \mathrm{~kW}$ ) solar PV system with a grid444 tied/stand-alone control and built-in battery energy storage element. Through the analysis 445 of the actual ship's experimental data under the conditions of arrival/departure and normal 446 sailing, the following conclusions can be drawn.

447 1. In the case of arrival/departure, when the ship's load is low, the solar output power 448 should preferably be $60-90 \mathrm{~kW}$. When the ship's load is high, the solar output power 449 should be between $72-90 \mathrm{~kW}$. If the entire ship remains in the power range recommended 450 above, its fuel economy will be optimal.

2. Under normal sailing conditions, the greater the output power of solar energy, the 452 better the energy saving and emission reductions at peak power.

3. When ships are sailing using a solar energy hybrid power system, they can reduce

454 fuel consumption by a maximum of $4.02 \%$ and $\mathrm{CO}_{2}$ emissions by a maximum of $8.55 \%$ 455 in a year.

4564 . The solar hybrid energy system design scheme in this paper can be applied to and 457 provide significant guidance for the same type of ships, distributed power stations and 458 microgrid systems.

\section{Acknowledgments}




\section{References}

465 [1]International energy agency in world energy outlook. International Energy Agency, [2018-01-04].

466 http://www.worldenergyoutlook.org.

467 [2]Ma Dong, Ding Yan, Yin Hang, etc. Outlook and status of ship and ports Emission Controlin China.

468 Environment and sustainable development, 2014, 39(6): 40-44. (In Chinese)

469 [3]Buhaug O, Corbett J J, Eyring V, et al. Prevention of Air Pollution from Ships: second IMO GHG Study. 470 International Maritime Organization, London, 2009.

471 [4]Plotting a more sustainable course for the international shipping sector. International Energy Agency,

472 2017-10-03 [2018-01-04]. http://www.iea.org/newsroom/news.

473 [5] Bicer Y, Dincer I. Clean fuel options with hydrogen for sea transportation: A life cycle approach. 474 International Journal of Hydrogen Energy, 2018, 43(2):1179-1193.

475 [6] Abkenar A T, Nazari A, Jayasinghe S D G, et al. Fuel Cell Power Management Using Genetic 476 Expression Programming in All-Electric Ships. IEEE Transactions on Energy Conversion, 2017, (99): 1-1.

477 [7] Kotrikla A M, Lilas T, Nikitakos N. Abatement of air pollution at an aegean island port utilizing shore 478 side electricity and renewable energy. Marine Policy, 2015, 75: 238-248.

479 [8] Salem A A, Seddiek I S. Techno-Economic Approach to Solar Energy Systems Onboard Marine 480 Vehicles. Polish Maritime Research, 2016, 23(3): 64-71. 
[10] Sichilalu S, Mathaba T, Xia X. Optimal control of a wind-PV-hybrid powered heat pump water heater. energy system (HRES) for stand-alone usages by an optimization-simulation model: Case study of Iran.

490 [13] Diab F, Lan H, Ali S. Novel comparison study between the hybrid renewable energy systems on land 491 and on ship. Renewable \& Sustainable Energy Reviews, 2016, 63:452-463.

492 [14] Kobougias I, Tatakis E, Prousalidis J. PV Systems Installed in Marine Vessels: Technologies and 493 Specifications. Advances in Power Electronics, 2013, 831560: 1-9, http://dx.doi.org/10.1155/2013/831560

494 [15] Tsekouras G J, Kanellos F D, Prousalidis J. Simplified method for the assessment of ship electric 495 power systems operation cost reduction from energy storage and renewable energy sources integration. IET 496 Electrical Systems in Transportation, 2015, 5(2): 61-69.

497 [16] Basu A, Kumar B, Rana S, et al. Solar and ocean thermal energy operated hi-tech ship having 498 passenger safety and desalination facilities. Industrial Automation and Electromechanical Engineering 499 Conference, 2017: 52-55.

500 [17]Zhu Y, Zhou S, Feng Y, et al. Influences of solar energy on the energy efficiency design index for new building ships. International Journal of Hydrogen Energy, 2017, 42(30): 19389-19394. 
504 18(1): 40-45.

[19] Liu H, Zhang Q, Qi X, et al. Estimation of PV output power in moving and rocking hybrid energy

509 [21] Atkinson G M. Analysis of marine solar power trials on Blue Star Delos. Journal of Marine

510 Engineering \& Technology, 2016, 15(3): 115-123.

511 [22] Wen S, Lan H, Hong Y Y, et al. Allocation of ESS by interval optimization method considering impact

512 of ship swinging on hybrid PV/diesel ship power system. Applied Energy, 2016, 175: 158-167.

513 [23] Lan H, Wen S, Hong Y Y, et al. Optimal sizing of hybrid PV/diesel/battery in ship power system.

514 Applied Energy, 2015, 158: 26-34.

515 [24] Kokusho T, Emoto E, Kato T. Sailing Solar-Cell Raft Project and Weather and Marine Conditions in

516 Low-Latitude Pacific Ocean. Journal of Energy Engineering Asce, 2013, 139(1): 2-7.

517 [25] Kyoung-Jun Lee, Dongsul Shin, Dong-WookYoo, et al. Hybrid photovoltaic/diesel green ship 518 operating instandalone and grid-connected mode-Experimental investigation. Energy, 2013, 49(1): 475-483.

519 [26] Chian ship trading network. Fuel prices of major international ports, [2018-07-30]. http://www.cn- 